\section{Researchers fight poaching with presence, not guns}

SIR - Your News Feature 'Peaceful primates, violent acts' (Nature 447, 635-636; 2007) reports on the conflicts that arise when wild animals studied for research are threatened by poaching and the bush-meat trade. Regional and international conservation organizations can help, but sometimes individual researchers feel that more immediate measures are required. Local presence has been shown to be one of the most efficient conservation actions, and many research programmes, including the bonobo research project of the Max Planck Institute, have taken risks in continuing to work even when unrest prevails.

You tell the story of Jonas Eriksson, a $\mathrm{PhD}$ student who left his academic career to engage in an unusual form of conservation action. From your report, readers may have gained the impression that Eriksson has been engaging in firefights using guns obtained illegally, but this was not the case. The aim of the project was to strengthen the capacity of the guards of the Congolese wildlife authority (ICCN) and to lead joint patrols of villagers and park guards into areas of Salonga National Park where poachers operate. The guards from ICCN are armed with automatic weapons that are owned by the wildlife authority, with a mandate to use them for law enforcement.

We emphasize that the anti-poaching project is neither typical nor representative of the work of the Max Planck Society. Researchers at LuiKotal, in Salonga National Park, have never been armed. Carrying arms would violate national and international laws, and would be counterproductive to the goals of our research.

Conservation and research have to go hand in hand, without weapons. The pressures that we can exert are physical presence and a strong motivation to protect those who provide us with the information we seek. This is what Eriksson did when he started his Salonga mission, and it is what other researchers from our institute do at their field sites across the African continent.

\section{Gottfried Hohmann}

Max Planck Institute for Evolutionary

Anthropology, Deutscher Platz 6,

04103 Leipzig, Germany

\section{Estimating the cost of climate change}

SIR - Your News in Brief story 'Germany counts the costs of climate change' (Nature 446,$360 ; 2007$ ) reports the conclusions of a study by the German Institute for Economic Research (DIW) that you state is based on my work. This is not correct. As I had previously documented (R. Roson and R. Tol Integr. Assess. 6, 75-82; 2006), the DIW model is based on egregious misinterpretation of my work.

The German gross domestic product (GDP) was about $€ 2,000$ billion (US $\$ 2,700$ billion) in 2006. If the German economy grows by $1.65 \%$ per year without climate change and $0.5 \%$ slower with climate change, as the DIW study suggests, then the gap between the two scenarios is the $€ 800$ billion in 2050 that you reported. This corresponds to $20 \%$ of German GDP in 2050, without climate change. This is at the upper end of the range of the Stern Review. However, you call the DIW study "less pessimistic" than the Stern Review.

You are correct to say that my estimates of the impacts of climate change are lower than those of the Stern Review, and, by implication, the DIW study. Indeed, as I showed earlier (R. Tol Energy Policy 33, 2064-2074; 2005), peer-reviewed estimates are lower than estimates in the grey literature. Neither the DIW study nor the Stern Review were reviewed by independent peers. Richard Tol

Economic and Social Research Institute, Whitaker Square, Sir John Rogerson's Quay, Dublin 2, Ireland

\section{Not so sunny view of the events in Arizona}

SIR - You seem so bedazzled by President Michael Crow's brutal reshaping ('The Arizona Experiment' Nature 446, 968-970; 2007) of Arizona State University (ASU) that I could not help thinking of Stephen Poliakoff's Blinded by the Sun, a play depicting the cold-fusion debacle. Your comment "Take Robert Pettit - a chemist and long-time director of the Cancer Research Institute at ASU until he lost the position in 2005" hardly touches on the ferociousness of President Crow and the events you describe. John C. Knight, in Correspondence, described those events differently (Nature 447, 528; 2007).

Pettit is probably one of the most prolific and productive scientists at ASU. He has published more than 750 articles in the cancer field, and was responsible through his own prodigious funding efforts for the construction, maintenance, operation and staffing of the institute. The efforts of Pettit, his students and collaborators are known worldwide, thanks to their investigations during the past 30 years of the anti-cancer properties of natural marine products. The institute brought more funds to ASU, through its patent income, than any other inventor.

Pettit's institute was closed with startling lack of notice and the staff of more than 60 people were marched out of the building on 27 January 2006 by security personnel (see Chemical and Engineering News 10, 6 February 2006). In terms of harsh abruptness, this step must be unprecedented in US academic history.

A pending, multi-million dollar suit against Crow and ASU filed by the

Government Accountability Project with the US District Court in Phoenix may yet shed light on this sorry affair.

More often than not, excessive sunshine produces sunburn, some of it even fatal. Carl Djerassi

Department of Chemistry, Stanford University, Stanford, California 94305-5080, USA

\section{Why are people reluctant to join in open review?}

SIR - I was excited when Nature launched its trial for open peer review last year, but disappointed by the outcome (see http:// blogs.nature.com/nature/peerreview/trial). I have also been tracking the progress of another open review journal, Biology Direct (www.biology-direct.com; see article in Nature's peer-review debate at www.nature. $\mathrm{com} /$ nature/peerreview/debate/nature 05005 . html). Even after a high-profile launch with guaranteed indexing by PubMed, this journal has published only 52 articles and received only two comments over 16 months.

In contrast to Biology Direct, another journal that offers open commenting, PLoS One (www.plosone.org), has published 1,189 articles in its first six months. But has PLoS One achieved its stated goal of post-publication open comments? I find that even the 'most annotated' category of articles usually receives just a few comments. The journal has recently replaced its 'most annotated' with a 'recently annotated' category. A check of all 'recently annotated' articles demonstrates that their commenting rates are low (zero or just a few), even for articles that are likely to have broad appeal and/or are in 'hot' research areas.

Why is there a general lack of interest among the scientific community in open commenting on submitted or published papers? I believe there are two main reasons. First, participation does not earn any tangible credit or benefit for the reviewers and commentators. Second, publicly critical comments are a risk for those who make them.

Shi V. Liu

Scientific Ethics, Apex, North Carolina 27502, USA http://im1.biz

SVL8SE@im1.biz

Science publishing issues are regularly featured at Nautilus (http://blogs.nature. com/nautilus), where debate is welcomed. 